\title{
ANALYSIS OF SEPAK TAKRAW TRAINING PROGRAMS IN SMA NEGERI KEBERBAKTAN OLAHRAGA BENGKULU PROVINCE
}

\section{ANALISIS PROGRAM LATIHAN SEPAK TAKRAW DI SMA NEGERI KEBERBAKTAN OLAHRAGA PROVINSI BENGKULU}

Ice Trisna Wati ${ }^{1}$, Martiani ${ }^{2}$

${ }^{1}$ Study Program Phsycal Education Study Program, Universitas Dehasen Bengkulu, Indonesia

2.Departemen Phsycal Education Study Program, Universitas Dehasen Bengkulu, Indonesia
Corresponding Author: : icetw@gmail.com

\section{How to Cite :}

Wati.I.T., Martiani. (2020). Analysis Of Sepak Takraw Training Programs In SMA Negeri Keberbaktan Olahraga Bengkulu Province. Hanoman Journal, 1(1)

ARTICLE HISTORY

Received [ $x x$ Month $x x x x$ ]

Revised [ $x x$ Month $x x x x$ ] Accepted [ $x x$ Month $x x x x]$

Kata Kunci :

Program Latihan, Sepak

Takraw

Keywords :

Training Program, Sepak Takraw

This is an open access article under the $C C-B Y-S A$ license

\begin{abstract}
ABSTRAK
Penelitian ini bertujuan untuk mengetahui pelaksanaan program latihan sepak takraw dengan menerapkan metode tringulasi yaitu pedoman wawancara, pedoman observasi dan pedoman studi dokumentasi. Pada atlet SMA Negeri Keberbakatan Olahraga Provinsi Bengkulu. Jenis penelitian ini adalah kualitatif. Subjek penelitian ini adalah atlet SMA Negeri Keberbakatan Olahraga Provinsi Bengkulu dengan jumlah atlet yaitu 12 orang. Berdasarkan hasil penelitian dapat disimpulkan bahwa penerapan metode wawancara, observasi dan studi dokumentasi pada pelaksanaan program latihan sepak takraw yaitu langsung melibatkan pelatih. Pelatih memberikan latihan kepada atlet setiap hari senin hingga jum'at yang dilakukan 2 kali dalam sehari yaitu pagi dari pukul 05.30 hingga 07.30 WIB dan di sore harinya yaitu pukul 16.00 hingga selesai. Selanjutnya program latihan sepak takraw di SMA Negeri Keberbaktan Olahraga Provinsi Bengkulu telah terprogram dan berkesinambungan. Hal ini dapat di buktikan dari program latihan, jadwal latihan dan pelatih yang menangani pembinaan dan pelaksanaan tersebut.
\end{abstract}

\begin{abstract}
This study aims to find out the implementation of sepak takraw training program by applying the tringulation method namely interview, observation and documentation study guidelines on athletes at SMA Keberbakatan Olahraga of Bengkulu Province. The type of research is a qualitative. The subjects of this study were 12 athletes at SMA Keberbakatan Olahraga of Bengkulu Province. Based on the results of the study, it can be concluded that the implementation of sepak takraw training program involves the coach directly. The coach provides training to athletes every Monday to Friday which is conducted twice a day, namely morning from 05:30 to 07:30 WIB and in the afternoon that is 16:00 to finish. Furthermore, the sepak takraw training program at SMA Keberbakatan Olahraga of Bengkulu Province has been programmed and continuous. This can be proven from the training program, training schedule and the coach who handle the training and implementation.
\end{abstract}

SMA Negeri Keberbakatan Olahraga Provinsi Bengkulu terletak di JL. Raya Halmahera Kota Bengkulu merupakan salah satu sekolah yang melakukan pembinaan dalam melahirkan atlet yang berprestasi, karena sekolah ini, khusus untuk olahrawan yang berprestasi. Sekolah Keberbakatan Olahraga adalah salah satu sekolah yang terletak di Provinsi Bengkulu. Di Sekolah Keberbakatan Olahraga (SKO) 
ini sangat menitik beratnya eksternal daripada internal karena sekolah ini khusus atlet, jadi ekstra sangat penting untuk penunjang prestasi pada atlet itu. Apabila sang atlet tidak melakukan ekstra maka tidak adanya peningkatan prestasi yang akan diraih. Salah satu faktor yang mempengaruhi kemampuan dan peningkatan atlet untuk meraih prestasi adalah dengan melakukan ekstra yang banyak dan motivasi yang kuat agar dapat menggerakkan sang atlet untuk giat dalam prestasi internasional.

SMA Negeri keberbakatan Olahraga prestasi Provinsi Bengkulu merupakan sekolah pertama diprovinsi bengkulu yang menciptakan atlet-atlet dari perkabupaten Provinsi Bengkulu. Atlet yang diangkut merupakan atlet yang berprestasi dari cabang olahraga yang dikuasai masing-masing dan dari sejumlah kabupaten yang berbedabeda Provinsi Bengkulu. Sekolah ini memperoleh beasiswa bagi seluruh siswa, jadi para siswa tidak dipungut biaya sedikitpun melainkan mendapat tunjangan beasiswa dari pihak sekolah. Berdasrkan survei awal pada tanggal 27 febuari 2017 lalu di SMA Negeri Keberbakatan Olahraga Provinsi bengkulu pada tanggal akan tetapi para atlet dituntut penuh dalam meniti atau mendapatkan prestasi pada cabang olahraga yang telah dipilih. Penerimaan siswanya pun tidaklah formal atau seperti sekolah-kolah biasa pada umumnya sebab ada beberapa prosedur atau tahap-tahapan bagi atlet salah satunya adalah dengan tes fisik, tes ini akan menetukan perkembangan atau batas mana seorang atlet bisa dikatakan berprestasi dan bisa masuk di sekolahh tersebut. Setelah semua tes telah dilakukan dan sudah mendapatkan hasil para atlet yang berprestasi, sekolah ini juga menuntut kepada para atlet setiap tahunnya harus mendapatkan perkembangan atau prestasi yang lebih baik dari sebelumnya.

\section{LANDASAN TEORI}

Dalam suatu organisasi atau perkumpulan olahraga harus ada pembinaan nantinya dapat menghasilkan suatu prestasi yang bagus, dan diharapkan dalam pembinaan program latihan harus melihat pada setiap individu pamain atau atlet baik dalam pertumbuhan dan pengembangannya. Tahap-tahap pembinaan program latihan yang baik untuk mencapai prestasi tinggi menurut KONI ,Gerakan Nasional Garuda Emas (1997-2007 )yaitu :

1) Tahap Latihan Persiapan (Multilateral)

Tahap ini merupakan tahap dasar untuk memberi kemampuan, memberikan kemmapuan dasra yang menyeluruh (multilateral) kepada atlet dalam aspek fisik, mental, dan sosial. Pada tahap dasar ini, atlet yang berprestasi diarahkan ke tahap spesialisasi, akan tetapi latihanya harus mampu membentuk kerangka tubuh yang kuat dan benar, khususnya dalam perkembangan biomotorik, gunu menunjang peningkatan prestasi di tahapan latihan berikutnya.

2) Tahap Latihan Pembentukkan (Spesialisasi)

Tahap latihan ini adalah, untuk merealisasikan terwujudnya profil atlet seperti yang diharapkan, sesuai dengan cabang olahraganya masing-masing. Kemampuan fisik, maupun teknik telah terbentuk, demikian pula keterampilan taktik, sehingga dapat digunakan atau dipakai sebagai titik tolak pengembangan, serta peningkatan prestasi selanjutnya. Pada tahap ini, atlet dapat dispesialisasikan pada satu cabang olahraga yang palaing cocok atau sesuai baginya.

3) Tahap Latihan Pemantapan

Profil yang telah diperoleh pada tahap pembentukan, lebih ditingkatkan pembinaannya, serta disempurnakan sampai kebatas optimal atau maksimal. Tahap pemantapan ini merupakan usaha pengembangan potensi atlet 
semaksimal mungkin, sehingga telah dapat mendekati atau bahkan mencapai puncak prestasinya.

4) Golden Age

Sasaran tahapan-tahapan pembinaan adalah agar atlet dapat mencapai prestasi puncak (golden age). Tahapan ini didukung oleh program latihan yang baik, dimana perkembangannya dievaluasi secara periodik. Dalam tahap latihan pemantapan, keadaan atlet disiapkan untuk mencapai prestasi puncak. Di dalam tahap pembibitan pembinaan harus dilakukan secara terprogram, terarah dan terencana dengan baik. Baik dari segi manajemen secara umum maupun manajemen kepelatihan secara khusus.

\section{Program Latihan}

Suatu pengelolaan olahraga dibutuhkan program latihan yang sistematis dalam pencapaian prestasi meksimal. Penyusunan program latihan merupakan suatu strategi usaha untuk mencapai tujuan masa depan atlet seoptimal mungkin. Program latihan yang diberikan merupakan suatu petunjuk akan perkembangan pembinaan yang dilaksanakan demi tercapainya tujuan maksimal.

Manfaat program latihan: 1) merupakan pedoman kegiatan yang terorganisir untuk mencapai prestasi puncak suatu cabang olahraga. 2) untuk menghindari faktor kebetulan dalam mencapai prestasi puncak dalam olahraga. 3) efektif dan efisien dalam penggunaan waktu, dana, tenaga untuk mencapai tujuan. 4) untuk mengetahui hambatan-hambatan dengan cepat dan menghindari pemborosan waktu, dana dan tenaga. 5) memperjelas arah dan tujuan yang ingin dicapai. 6) sebagai alat kontrol terhadap tercapainya sasran (Tohar, 2008:32).

Perkembangan fisik, pembinaan serta peningkatan prestasi hanya dapat dikembangkan melalui satu program latihan jangka panjang oleh karena itu perubahan-perubahan organisasi mekanis new-physiologis perkembangan jaringanjaringan tidak mungkin dengan jarak yang pendek (Tohar,2008:19). Dari dasar-dasar berarti perkembangan tersebut membutuhkan waktu lama (sekitar 8-10 bulan), maka jadwal latihan harus terbagi dalam beberapa tahapan atau musim latiahn, sehingga dalam musim latihan pelatih pada suatu aspek latiahan. Andi Suhendro (2002) membagi program latihan menjadi 3 bagian, yaitu:

1. Program Jangka Panjang

Program jangka panjang merupakan program latihan dengan kurun waktu antara 5 sampai 12 tahun. Tujuan rencana jangka panjang merupakan tujuan akhir untuk mencapai prestasi seoptimal mungkin. Rencana jangka sebenarnya merupakan pedoman instruksi tidak langsung terhadap jangka menegah dan pendek. Dengan kata lain rencana jangka pendek merupakan pelaksanaan langsung rencana jangka menegah merupakan pelaksanaan langsung rencana jangka panjang.

2. Program Jangka Menengah

Program jangka menegah merupakan program latihan dengan jangka waktu kurun antara 2 sampai 4 tahun. Telah dijelaskan di atas bahwa rencana jangka menengah merupakan pelaksanaan langsung dari rencana jangka panjang. Sebagai contoh, struktur rencana jangka menengah kegiatan olahraga di Indonesia adalah kejuaraan Nasional yang dilaksanakan setiap 2 tahun sekali adalah untuk menuju PON yang diadakan setiap 4 tahun sekali, hasil PON adalah untuk menuju Sea Games, berikutnya hasil Sea Games menuju Asean Games dan selanjutnya menuju Olympic Games.

3. Program Jangka Pendek

Program jangka pendek merupakan program latihan tahunan dengan kurun waktu latihan selama 1 tahun. Program jangka pendek merupakan pelaksanaan 
operasional rencana jangka menengah. Sasaran-sasaran latihanpun merupakan penjabaran sasaran dari program jangka menengah.

\section{Aspek Latihan}

Menurut Harsono (1988-12), tujuan utama pelatihan olahraga prestasi adalah untuk meningkatkan keterampilan atau prestasi semaksimal mungkin. Untuk mencapai tujuan itu, ada empat aspek latihan yang perlu dilatih secara seksama yaitu :

1. Latihan Fisik

Latihan fisik adalah latihan yang bertujuan untuk meningkatkan kondisi fisik, yaitu faktor yang amat penting bagi setiap atlet. Tanpa kondisi fisik yang baik atlet tidak akan mengikuti latihan-latihan, apalagi bertanding dengan sempurna. Beberapa unsur kemampuan fisik dasar perlu dikembangkan antara lain ialah kekuatan, daya tahan, kelentukkan, kelincahan dan kecepatan.

2. Latihan Teknik

Latihan teknik adalah latihan yang bertujuan untuk mempermahir penguasaan keterampilan gerak dalam suatu cabang olahraga, seperti misalnya teknik menedang, melempar, menagkap, mengiring bola, melompat, lari dsb. Penguasaan keterampilan dari teknik-teknik dasar amatlah penting karena akan menetukan kemahiran melakukan keseluruhan gerak dalam suatu cabang olahraga.

3. Latihan Taktik

Latihan taktik bertujuan untuk mengembangkan dan menumbuhkan daya tafsir pada atlet ketika melaksanakan kegiatan olahraga yang bersangkutan. Yang dilatih adalah pola-pola permainan, strategi dan taktik pertahanan dan penyerangan. Latihan taktk akan bisa berjalan mulus apabila teknik dasar sudah dikuasai dengan baik dan atlet mempunyai tingkat kecerdasan yang baik pula.

4. Latihan mental

Latihan mental sama pentingnya dengan ketiga asek tersebut di atas sebab betapa sempurnanya perkembangan fisik, teknik, serta taktik atlet, apabila mentalnya tidak turut berkembang, prestasi tinggi tidak mungkin dapat dicapai.

\section{Pertahapan Latihan}

Menurut Rubianto Hadi (2007:63) pertahapan latihan dibagi menjadi beberapa tahap, yaitu:

1. Tahap Latihan Dasar

Merupakan tahap latihan awal yang harus dilewati oleh atlet muda sebelum masuk dalam sesialisasi cabang yang ditekuni. Pencarian bakat bukanlah hal yang mudah tanpa melalui pelaksanaan aktivitas pada berbagai gerakan motorik, cabang olahraga maupun kemampuan kondisi fisik yang sesuai. Tujuan dari latihan ini adalah memberikan landasan yang baik kepada atlet muda berkaitan dengan aspek fisik, mekanik psikologi dan moral sebagai prekondisi untuk mencapai hasil yang baik melalui kemampuan pengembangan, keterampilan dan karakter.

2. Tahap Latihan Lanjutan

Tahap lanjutan merupakan tahap penghubung dari tahap latihan dasr menuju tahap prestasi tinggi. Pada tahap ini, tujuan latihan adalah untuk memperkuat fondasi keterampilan, kualitas dan kemampuan fisik dan melakukan latihan yang lebih khusus pada cabang olahraga atau yang dtekuni.

3. Tahap Prestasi Tinggi 
Tahap ini merupakan bagian terakhir pada seluruh proses latihan. Tujuan pada tahap ini adalah kemampuan atlet untuk mengikuti kejuaraan nasional dan internasional serta mencatatkan prestasi terbaik.

\section{METODE PENELITIAN}

Penelitian ini bertujuan untuk megetahui bagaimana pelaksanaan program latihan sepak takraw di SMA Negeri Keberkatan Olahraga Provinsi Bengkulu. Jenis dari penelitian ini termasuk kedalam penelitian deskriptif kualitatif. Sugiyono (200812) mengemukakan penelitian kualitatif dinamakan metode baru, karena popularitasnya belum lama, dinamakan metode postpositivistik karena berlandaskan pada filsafat postpositivisme. Metode ini disebut juga sebagai metode artistik, karena proses penelitiannya lebih bersifat seni (kurang terpola) dan disebut juga sebagai metode interpretive karena data hasil penelitian lebih berkenaan dengan interpretasi terhadpa data yang ditemukan dilapangan.

\section{HASIL}

Berdasarkan hasil pengamatan dan penelitian pelaksanaan program latihan sepak takraw yang dilakukan pada atlet SMA Negeri Keberbakatan Olahraga yang beralamat di Jl. Halmahera No.1. RT. 07, RW.04 Kecamatan Sungai Serut, Kelurahan Surabaya, Kota Madya Bengkulu. Pada tanggal 11 April 2019 hingga 24 April 2019. Teknik pengumpulan data pada penelitian ini didukung dengan wawancara, obsrevasi, dan dokumentasi untuk memperkuat penelitian yang dilaksanakan penelitian. Teknik ini merupakan pengumpulan data yang dilakukan dengan cara memberikan pertanyaan tertulis kepada responden untuk menjawabnya, pengumpulan data dilakukan pada sumber data yaitu kepada pelatih dan Atlet sepak takraw.

Berdasarkan penelitian yang peneliti lakukan pada metode wawacara, observasi dan dokumentasi menyimpulkan bahwa pelaksanaan program latihan sepak takraw di SMA Negeri Keberbakatan Olahraga Provinsi Bengkulu yaitu langsung melibatkan pelatih, pelatih sepak takraw SMA Keberbakatan Olahraga Provinsi Bengkulu ada 2 orang pelatih dan sudah mempunya lisensi. Pelatih memberi latihan kepada atlet setiap hari senen sampai dengan jumat yang dilakukan 2 kali dalam sehari yaitu pagi dari pukul 05.30 WIB hingga 07.30 dan sore hari dari jam 16.00 WIB hingga selesai. Latihan dalam sepak takrawpun mempunyai selang seling dalam latihan misalnya senen merupakan latihan taktik pada hari selasa itu melakukan latihan fisik sampai dengan jumat seperti itu. Latihan ditambah jika sudah mendekati pertandingan dalam latihan fisik diterapakan bentuk latihan yaitu kelentukan, kekuatan, daya tahan, kecepatan serta kesimbangan. Sedangkan latihan fisiknya lebih sering diluar lapangan karena ada bentuk fisik yaitu balke test, sprint $10 \mathrm{~m}$ sampai $20 \mathrm{~m}$, bleep test, dan strengh endurance di gedung olahraga yang ada di SMA Negeri Keberbakatan Olahraga itu sendiri. Tetapi dalam metodenya masih kurang bervariasi dan latihan teknik dilakukan disetiap pertemuan untuk memperbaiki teknik dasar dan memaksimalkan teknik yang sudah ada.

pada penelitian pertama hari kamis 11 April 2019 dimana 9 atlet yang hadir dalam latihan dimulai dari waktu 16.00 WIB sebelumnya atlet diharuskan terlebih dahulu hadir ketimbang pelatih jadi atlet akan melakukan pemananasan sendiri pemanasan statis dan dinamis sambil menunggu pelatih, setelah pelatih datang pelatih akan memberi tujuan dari latihan dan latihan akan berlangsung dengan durasi 15 sampai 20 menit sebelum masuk kedalam game, dimana pada hari ini latihan yang akan diterapkan yaitu fisik. Terdiri dari kelentukan, kekuatan, daya 
tahan, kecepatan keseimbangan dalam bentuk latihan yaitu balke test, sprint $10 \mathrm{~m}$ $20 \mathrm{~m}$, bleep test dan strengh endurance.

Penelitian dilanjut pada latihan hari kedua jumat 12 April 2019 hampir sama pada hari pertama hanya saja yang membedakanya adalah pada hari ini latihan fokus pada latihan teknik dan jumlah atlet yang hadir sekitar 6 orang, dengan bentuk latihan berupa passing, tekong, blok, servis, dan smash. Pada ketiga yaitu senen 15 April 2019 penelitian sama persis dengan penelitian pada hari kamis sebab telah dijelaskan bahwa program harian yang dijalan SMA Negeri Keberbakatan Olahraga Provinsi Bengkulu berupa latihan selang seling atau bergantian dengan 2 kategori latihan yaitu latihan teknik dan fisik.

Penelitian berlanjut pada penelitian hari keempat selasa 16 April 2019 dengan kategori latihan sama persis dengan hari jumat sebab latihanya adalah fiisk. Dan hari berikut sampai seterusnya hanya mengikuti perselang-selingan dari program harian yang harus dijalankan.

Program latihan di SMA Negeri Keberbakatan Olahraga Provinsi Bengkulu inipun memiliki kepalatihan atau pembinaan yang masih terkait dengan DISPORA program latihan sepak takrawpun diberi oleh pihak DISPORA Untuk dijalan di SMA Negeri Keberbakatan Olahraga Provinsi Bengkulu. Situasi dan kondisi dari program latihan sepak takraw yang ada di SMA Negeri Keberbakatan Olahraga inilah yang menjadi tolak ukur peneliti untuk menganalisis pelaksanaan program latihan di lapanagan. Hal ini dapat dibuktikan dari hasil wawancara kepada pelatih sepak takraw yaitu Bapak Erizal bahwa beliau menjelaskan menjalankan program latihan yang diberikan oleh pihak dispora.

\section{PEMBAHASAN}

Berdasarkan hasil penelitian secara umum menunjukan bahwa prlaksanaan program latihan sepak takraw di SMA Negeri KeberbakataN Olahraga Provinsi Bnegkulutergolong dalam kategori cukup baik. Hal ini dapat dibuktikan dari hasil penelitian yang telah dilakukan meliputi program latihan selma latihan dan hasil penerapannya dilapangan. Berdasarkan hasil penelitian yang diperoleh dari tim sepak takraw di SMA Negeri Keberbakatan Olahraga Provinsi Bengkulu, tujuan utama diadakan pelaksanaan program latihan di SMA Negeri Keberbakatan Olahraga Provinsi Bengkulu adalah Menghasilkan lulusan yang profesional di bidang olahraga sehingga dapat menjadi atlet handal nasional maupun internasional. Agar mendapat arahan yang terencana dan terprogram untuk meningkatkan prestasi tim sepak takraw SMA Negeri Keberbakatan Olahraga Provinsi Bengkulu .

Sasaran tahapan-tahapan pembinaan adalah agar atlet dapat mencapai prestasi puncak (golden age). Tahapan ini didukung oleh program latihan yang baik, dimana perkembangannya dievaluasi secara periodik. Dalam tahap latihan pemantapan, keadaan atlet disiapkan untuk mencapai prestasi puncak. Di dalam tahap pembibitan pembinaan harus dilakukan secara terprogram, terarah dan terencana dengan baik. Baik dari segi manajemen secara umum maupun manajemen kepelatihan secara khusus.

Berdasarkan data lapangan dan analisis tentang pelaksanaan program latihan sepak takraw di SMA Negeri Keberbakatan Olahraga Provinsi Bengkulu yang dideskripsi dari manajemen kepengurusan, perekrutan pelatih dan, pelaksnaan program latihan, sarana dan prasarana yang menunjang, serta sistem pendanaan ditemukan banyak permasalahan yang mempunyai faktor pendukung dan penghambat jalannya proses pelaksanaan, sehingga masih bisa bertahan dalam mengembangkan olahraga sepak takraw. 
Faktor pendukung misalnya seperti: (1) prestasi atlet tim sepak takraw yang cukup meningkat sehingga atlet latihan atlet tidak terhenti dan masih bersemangat dalam menjalankan latihan program latihan, (2) komitmen dan konsisten dari pelatih untuk semakin mengembangkan pelaksanaan program latihan di SMA Negeri Keberbakatan Olahraga Provinsi Bengkulu dengan semua keterbatasan, (3) adanya dukungan dari orang tua atlet untuk mengembangkan bakatnya. Misalnya orang tua selalu mengawasi atau sewaktu-waktu melihat anaknya berlatih maupun bertanding sehingga menjadi salah satu motivasi tersendiri bagi para atlet.

Faktor penghambat sebagai berikut: (1) Ditinjau dari manajemen kepengurusan, pengelolahannya belum secara maksimal, hal ini diakibatkan karena kepengurusan hampir semua dijalankan oleh satu orang atau beberapa orang saja, (2) minimnya pendanaan untuk melakukan event atau pertandingan besar karena hanya mengandalkan sumber dana dari pemerintah, jadi bila akan mengikuti event atau pertandingan dana yang digunakan sangat terbatas, (3) kurangnya separing partner.

Program latihan adalah komponen penunjang pencapaian prestasi puncak. Penyusunan program latihan merupakan strategi usaha untuk mencapai tujuan masa depan prestasi atlet seoptimal mungkin. Pelatih membuat rencana latihan dengan memiliah alternatif sebagai tuntutan yang perlu dilaksanakan untuk meningkat prestasi sekarang ke prestasi yang akan datang sebagai sasran yang ingin oleh atlet.

Setelah mendapatkan atlet yang profesional, pelatih harus membuat rencana latihan untuk mencapai tujuan yang telah ditentukan secara tepat. Rencana latihan merupakan mata rantai target atau sasaran akhir, sasaran antara sasaran yang objektif dan terukur. Program latihan dikatakan baik, tepat apabila dibuat dengan pertimbangan faktor-faktor penetu untuk mencapai tujuan, faktor-faktor tersebut antara lain: bakat atau materi atlet, kemampuan atlet, umur latihan, sarana dan prasarana, dana/pendanaan, lingkungan, tenaga pelatih, dan waktu yang tersedia.

Tidak hanya itu, disamping melaksanakan program latihan secara rutin, juga menyelenggarakan latih tanding dengan tim sekolah lain atau club lain, hal ini dimaksudkan untuk menguji dan sekaligus melatih penerapan teknik, taktik dalam bermain serta menanam jiwa atau mental bertanding kepada para atlet.

\section{KESIMPULAN}

1. Pelaksanaan program latihan di SMA Negeri Keberbakatan Olahraga Provinsi Bengkulu telah terprogram dan berkesinambungan, hal ini dapat dilihat dari program latihan, jadwal latihan dan pelatih yang menangani pembinaan atau pelaksanaan tersebut. Pelatih tim sepak takraw SMA Negeri Keberbakatan Olahraga Provinsi Bengkulu memiliki kompetensi yang sangat baik yang didukung dengan sertifikasi pelatih.

2. Kualitas pelatih tim sepak takraw SMA Negeri Keberbakatan Olahraga Provinsi Bengkulu dikatakan baik. Ini dikarenakan pelatih sudah mengenal sistem pelatihan dan dan menjalankan program latihan yang telah dirancang dan mempunyai sifat disiplin tinggi dan ketegasan pada par atlet.

3. Program latihan secara makro telah disusun berdasarkan program tahunan dan secara mikro disusun bedasarkan kebutuhan yang diperlukan dan latihan telah dilaksanakan sesuai dengan kriteria/ syarat latihan menuju peningkatan prestasi puncak.

\section{SARAN}

1. Sarana dan prasarana yang ada di GOR Sepak Takraw di SMA Negeri Keberbakatan Olahraga Provinsi Bengkulu cukup terbatas dan tergolong kurang 
lengkap hal ini dapat dilihat dengan jumlah bola buah, net, skipping dalam keadaan buruk,lapangan dan fasilitas lain penunjang latihan. Diharapkan sarana dan prasarana semakin ditingkatkan dAn dilengkapi.

2. Prestasi tim sepak takraw di SMA Negeri Keberbaktan Olahraga Provinsi Bengkulu cukup baik, prestasi ditingkat wilayah dan ditingkat kejurda sudah diraih. Hal ini dikarenakan tim sepak takraw SMA Negeri Keberbakatan Olahraga Provinsi Bengkulu didukung dengan pelatih yang memberikan pembinaan dengan baik kepada para atletnya.

\section{DAFTAR PUSTAKA}

1. Andi, Suhendro. 2002. Dasar-Dasar Kepelatihan. Jakarta: Universitas Terbuka Surakarta. Yuma Pustaka.

2. Handoko, Hani. 1995. Manajemen Penjas dan Olahraga. Jakarta Yuma pustaka.

3. Hindarto. 1991. Pembinaan Olahraga. Semarang. FIK UNES.

4. KONI. 2000. Gerakan Nasional Garuda Emas. Pemanduan dan Pembinaan Bakat Usia Dini, Buku I dan II . Jakarta: KONI

5. Miftakhurohman. 2015. Pembinaan prestasi Tim Sepak Takraw Putra Kabupaten Demak. Jawah Tengah. Depdikbud.

6. Ratinus, darwin \& Penghulu Basa. 1992. Olahraga Pilihan Sepak Takraw. Jakarta: Depdikbud.

7. Rifki, Achmad, Deny. 2016. Survei pembinaan pada pengkap persatuan Indonesia (PSTI). Jakarta . Cipta Prima Nusantara

8. Rubianto, Hadi. 2007. Ilmu Kepelatihan Dasar. Semarang: CV. Cipta Prima Nusantara.

9. Rusli, Lutan, Sudrajat rawirasaputra dan Ucup Yusup. 2000. Dasar-Dasar Kepelatihan. Depatermen Pendidikan Nasional.

10. Said, Junaidi. 2003. Pembinaan Olahraga Usia Dini. Semarang: FIK UNNES.

11. Sugiyono. 2013. Metode penelitian bisnis. ALFA BETA. Cv. Bandung .

12. Sukrorini. 2009. Pembinaan prestasi sepak takraw di Kabupaten Kebumen.Jakarta. Pusda.

13. Sulaiman. 2008. Alat Tes Keterampilan Sepak Takraw Bgi Atlet. Jawa Tengah. JPEHS

14. Tohar. 2008:3. Metode penelitian tindakan kelas. PT. Remaja Pusda. Jakarta.

15. UU No 3. 2005. Tentang Sistem Keolahragaan Nasional.

16. Zikrur Rahmad. 2017. Manajemen Penjas dan Olahraga. Yuma Pustaka. Kadipiro Surakarta. 